\title{
Evaluation of Changes in the Microbiological Quality, Physic-chemical Properties and Sensory Properties of Milk-based Snack "Milk Crisp" during Storage at Ambient Temperature
}

\author{
Bhujendra Soni ${ }^{*}$, Geeta Chauhan, S. K. Mendiratta, \\ Subhashis Mohapatra and Anuradha Yadav
}

\begin{abstract}
Division of Livestock Product Technology, Indian Veterinary Research Institute, Izatnagar, Bareilly-243122, Uttar Pradesh, India
\end{abstract}

*Corresponding author

\section{Keywords \\ Sensory evaluation, Milk crisp, Ready- to-cook milk-based snack (RTCMBS), Skim milk coagulum}

\section{Article Info}

\section{Accepted:} 04 August 2020 Available Online: 10 September 2020

\section{A B S T R A C T}

The present study was undertaken to develop a good quality and highly acceptable shelf stable ready to-cook milk-based snack, which can be stored for longer period under ambient temperature. In preliminary trials, a wide variety of starchy flours, alone or in various combinations and different levels of skim milk coagulum were tried for preparing milk-based snacks to reach most acceptable combination. Based on the results of preliminary trials, formulation containing $55 \%$ of skim milk coagulum along with different combinations of flours was selected as control for further studies. Incorporation levels of two different extenders were separately optimized. The treatments containing optimum level of extenders and control (without extender) were evaluated for different physicochemical characteristics along with yield, expansion percentage and percentage oil uptake etc. All sensory parameters were recorded between good to very good. Aerobically packaged milk-based snacks stored at $30 \pm 2{ }^{\circ} \mathrm{C}$ showed no marked changes in sensory, physico-chemical and microbiological qualities during storage up to 60 days. TBARS and $\mathrm{pH}$ values increased however, percentage oil uptake and expansion percentage were reduced during storage period. Thus, it can be concluded that technology developed for making shelf stable ready to-cook milk-based snack using skim milk coagulum can provide a nutritious, palatable product to the consumers and ensure effective utilization of skim milk.

\section{Introduction}

India is the largest producer of milk in the world. Milk utilization pattern shows that about half of the total production in India is used as liquid milk, $45 \%$ for the preparation of traditional milk products and $5 \%$ for the preparation of western milk products. Milk proteins are the most valuable leading component of milk and are often commercialized in a dehydrated form to extend its shelf-life, facilitate its use and reduce transportation costs. These play very important role in our nutrition and physical wellbeing. Furthermore, their use under controlled conditions to produce nutritional, 
functional or flavorful dairy products and occasionally impart biological activities has often been demonstrated. Improved living standards and changed life styles due to urbanization have increased the demand for processed milk products. However, dependence on cold chain for marketing resulted in slow growth of processed milk sector in our country. Hence, there is imperative need to develop safe and acceptable shelf stable milk products which can be stored /marketed without refrigeration facility. Snacks are one of the fastest growing sectors in the food industry due to their convenience and suitability. Utilization of skim milk coagulum in snack products can provide all essential nutrients specially protein which are absent in vegetable/cereal snacks. Consumers demand nutritious, convenient, tasty snacks that satisfy their hunger momentarily until the next meal. The snacks available in the market are mainly cereal based which are high in carbohydrates and low in protein contents. However, the delivery of nutrition via incorporation of milk in ready-to-eat expanded snacks is a relatively new concept and is motivated mainly by health concerns. The most effective means of achieving this is via the process of extrusion, a continuous cooking and puffing technology that have gained widespread use during last several decades for the production of a variety of expanded snacks and breakfast cereals. So, to impart nutritive value to these snacks particularly in the form of protein, addition of milk is a revolutionary step. Eating of such snacks may provide a balanced food in terms of nutritive value and are much preferred by the children and growing population due to their crispy and tasty nature, along with its variety of options which satisfy the satiety Center easily. Thus, a new approach to milkbased snack foods could be combining ingredients to make products that could compete effectively with potato or corn chips while delivering more protein and other micronutrients. Such products can easily be prepared by small scale entrepreneurs and women cooperatives without any need for sophisticated machinery. These types of products can be marketed without the need for refrigeration, since these have extended shelf life which may allow limitless marketing opportunities. Further the manufacturing of such products can be scheduled to coincide with the availability of raw materials or manufacturing capacity. Keeping these facts in mind, present study was undertaken to develop good quality dried ready-to-cook shelf stable milk-based snacks, which can be stored at ambient temperature for better distribution and marketing.

\section{Materials and Methods}

\section{Source of raw materials}

\section{Milk}

Milk for pursuing this study was procured from the Dairy Technology Section of Indian Veterinary Research Institute, Izatnagar, Bareilly (U.P.). The milk procured was pasteurized one with combination of cow and buffalo milk as per daily production at dairy farm. Skim milk used in this study was prepared by an electrically operated cream separator (model- crema/90, Chadha Sales PVT LTD., Dairy Equipment Engineers, Delhi-110054, India). The particulars of skimmed milk used for the preparation of RTCMBS were as follows:

\begin{tabular}{lccccc}
$\mathrm{ph}$ & Fat & SNF & Density & Protein & Lactose \\
\hline $6.67 \pm 0.05$ & $0.63 \pm 0.08$ & $8.09 \pm 0.12$ & $31.3 \pm 2.35$ & $2.95 \pm 0.31$ & $4.48 \pm 0.32$ \\
\hline \multicolumn{5}{c}{ (Result obtained from Ultrasonic Milk Analyzer Master classic LM2) }
\end{tabular}

\section{Ingredients}

Rice (Oryza sativa) flour, Wheat (Triticum aestivum) flour, Black gram (Phaseolus mungaRoxb), Green gram (Phaseolus auroux 
Rox), Gum tragacanth, Ascorbic acid, sodium carbonate, sodium bicarbonate, table salt and vegetable oil were purchased from the standard market of Bareilly, India.

\section{Chemicals}

All chemicals to be used will be of Analytical grade and obtained from standard firms (Qualigens, Hi Media, Polypharm, SRL etc.).

\section{Packaging material}

Low density polyethylene (LDPE) films (250 gauges) in natural colour were procured from the manufacturer, Polyethylene Industries, New Delhi, India for packing of the materials for storage studies.

\section{Process for preparation of ready to cook milk-based snacks "milk crisp"}

\section{Preparation of skim milk coagulum (SMC)}

An electrically operated cream separator used for skimming of milk. Skim milk coagulum was prepared by following the coagulation procedure of Bhattacharya et al., (1971) with alteration made as per the requirements of the experiment in question.

The cream separated "Skim milk" was heated to $85^{\circ} \mathrm{C}$ and cooled to $75^{\circ} \mathrm{C}$ for coagulation without holding. It was then coagulated adding $2 \%$ citric acid solution $(120 \mathrm{ml}$ per $\mathrm{kg}$ of milk). The coagulant solution was added slowly with constant stirring. After coagulation, the curd was transferred to muslin cloth and the whey was drained.

\section{Preparation of milk-based snack}

Finely minced skim milk coagulum and adequate precooked (Pregelatinized: The flour was blended for 5 min with boiling water at a set hydration ratio of $2: 1$ ) rice flour were mixed in home mixer (Lumix International, H.P., India) at high speed for 7 minutes. After adding wheat flour and salt, it was again mixed for 2 minutes. The kneaded batter/dough prepared by above process was put into a tray and placed in a steam chamber (inside pressure cooker) for 10 minutes. Next it was taken out of the steam chamber and cooled to room temperature, shaped with the help of kitchen press or shaper in tape like or rectangular form (shape), size $(4-6 \mathrm{~cm})$ and thickness $(1.05 \mathrm{~mm})$ uniformly over the tray.

The trays were placed in a hot air oven for drying at temperature of $45^{\circ} \mathrm{C}$ for 24 hours. Dried snack was cooled to room temperature, packed in low density polyethylene (LDPE) films (250 gauges), heat sealed and stored at ambient temperature $\left(37 \pm 2^{\circ} \mathrm{C}\right)$ till further use.

\section{Frying of milk-based snack}

Refined oil was taken in the deep fat fryer [Frendz® (2 litre capacity)] and heated to the temperature of $190^{\circ} \mathrm{C}$. When temperature reached at $190^{\circ} \mathrm{C}$ as indicated by the thermostat, the dried milk-based snacks were immersed into oil.

The snacks were taken out in 10-15 seconds after they were puffed properly and excessive oil was wiped off with a tissue paper.

\section{Experimental design}

Preliminary trials conducted to standardise the formulation and processing conditions for the preparation of Milk Crisps. It is a Ready to Cook product, which can be consumed after frying.

Milk crisp will be prepared by the incorporation of different levels of extenders i.e. Green gram and Black gram flour by replacing the amount of skim milk coagulum. 


\section{Analytical procedures}

\section{Physico-chemical Analysis}

\section{Product yield}

Weight of the batter prepared after adding water and the weight of the dried product after drying were recorded to calculate the product yield as follows:

Weight of the dried snacks

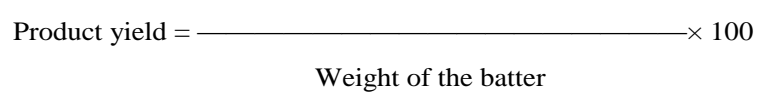

Weight of the batter

\section{Expansion percentage}

Area of the raw snacks (before frying) was measured using graph paper. Then snacks were fried at $190^{\circ} \mathrm{C}$ for $10-15$ seconds. The area of fried snacks was also measured as before and expansion percentage was calculated as follows (Bhattacharya et al., 1999):

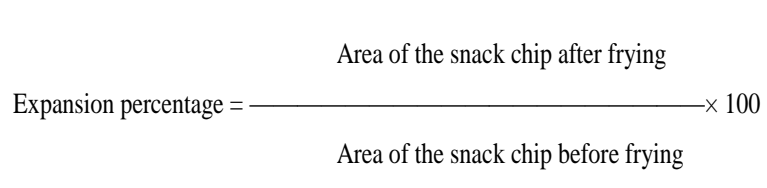

\section{Percentage oil uptake}

For measuring percentage oil uptake, weight of snacks was recorded before and after frying at $190^{\circ} \mathrm{C}$ for $10-15$ seconds in a deep fat fryer. After frying, excessive fat on the snacks was wiped off with a tissue paper before recording weight. Percentage oil uptake was recorded as follows (Pinthus et al., 1993):

Wt. of fried snacks - Wt. of the dried snacks

Percentage Oil uptake $=\longrightarrow \times 100$

Wt. of the dried snacks

\section{Warner-BratzlerShear force value}

Shear force value of fried milk-based snacks was determined using the texture analyser with a Warner -Bratzler blade attached to it (Smith et al., 1991). Milk based snack in the form of strip (approx. $1 \times 0.8 \mathrm{~cm}$ ) were taken for measuring shear force value. Each strip was placed in the shear force probe and shear force required to cut through the samples was recorded.

\section{Lovibond Tintometer Colour Units}

The colour of the milk-based snacks was measured using a Lovibond Tintometer (Model F, Greenwich, U.K.). Samples were finely ground in the home mixer, taken in the sample holder and secured against the viewing aperture.

The sample colour was matched by adjusting the red (a) and yellow (b) units, while keeping the blue unit fixed at 0 . The corresponding colour units were recorded. The chroma values were determined by using the formula $(\mathrm{a} 2+\mathrm{b} 2) 1 / 2$ (Froehlich et al., 1983), where $\mathrm{a}=$ red unit, $b=$ yellow unit.

\section{pH}

Ten grams of sample (after grinding in the home mixer for $1 \mathrm{~min}$.) was blended with 50 $\mathrm{ml}$ of distilled water for $1 \mathrm{~min}$. using an Ultra Turrax tissue homogenizer (Model T25, Janke and Kenkel, IKA Labor Technik, Germany). The $\mathrm{pH}$ of the homogenate was recorded (Trout et al., 1992) by immersing a combined glass electrode of a digital $\mathrm{pH}$ meter (Eutech Instruments, $\mathrm{pH}$ Tutor).

Thiobarbituric acid reacting substances (TBARS) number

The TBARS number of samples was determined by using the distillation method described by Tarladgis et al., (1960) and was expressed as $\mathrm{mg}$ malonaldehyde $/ \mathrm{kg}$ of sample.

\section{Proximate composition}

Moisture, crude fat, protein and ash contents 
of RTCMBS were determined by procedures prescribed by Association of Official Analytical Chemists (AOAC, 1995) using hot air oven, Soxhlet apparatus, Kjeldhal apparatus and Muffle furnace, respectively.Total carbohydrate determined by difference method (Pearson, 1976).Gross Energy calculated by using bomb calorimeter.

\section{Microbiological Analysis}

All the microbiological parameters were determined following the standard methods of APHA (2001). Readymade Media (Hi-Media, India) were used for all the microbiological examinations.

\section{Preparation of Serial Dilutions}

The stored samples of milk-based snack were opened in laminar flow chamber sterilized by ultra-violet irradiation. About $10 \mathrm{~g}$ of sample was aseptically weighed and transferred to a sterile mortar containing $90 \mathrm{ml}$ of sterile $0.1 \%$ peptone water. The sample was homogenized for 2 minutes using a sterile pestle to make $10^{-1}$ dilution. Further dilutions were made using sterile $0.1 \%$ peptone water as diluent. To prepare $10^{-2}$ dilution $1 \mathrm{ml}$ from $10^{-1}$ dilution was mixed with $9 \mathrm{ml}$ of $0.1 \%$ peptone water and so on. Proper mixing in serial dilutions was ensured by vortexing the test tubes. Preparation of sample and serial dilutions were made near flame in a horizontal laminar flow apparatus (Model: YS1-188, Varco Sales, Pvt. Ltd., New Delhi) observing all possible aseptic conditions.

\section{Total Plate Count (TPC)}

$23.5 \mathrm{~g}$ of plate count agar obtained from $\mathrm{Hi}-$ media laboratories Pvt. Ltd. Mumbai was suspended in $1000 \mathrm{ml}$ of distilled water followed by boiling to dissolve the medium completely. It was sterilized by autoclaving at $15 \mathrm{lbs}$ pressure $\left(121^{\circ} \mathrm{C}\right)$ for 15 minutes. Final
$\mathrm{pH}$ of the media was $7.0 \pm 0.2$ at $25^{\circ} \mathrm{C}$. Duplicate sets of sterilized petri-dishes were inoculated aseptically with $1 \mathrm{ml}$ of aliquots from appropriate dilutions. About 10-15 ml of sterilized medium was poured gently into each dish and rotated in clockwise and anticlockwise directions for 2-3 seconds to mix the media uniformly. The plates were inverted and incubated at $35 \pm 2^{0} \mathrm{C}$ for $48 \mathrm{hrs}$. After incubation, colonies were counted in plates with colonies between 30 and 300 . The number of colonies was multiplied by the reciprocal of the respective dilution and expressed as $\log _{10} \mathrm{cfu} / \mathrm{g}$.

\section{Yeast and Mould count}

Thirty-nine grams of Potato Dextrose Agar was suspended in $1000 \mathrm{ml}$ distilled water, boiled to dissolve the medium completely and sterilized by autoclaving at $121^{\circ} \mathrm{C}$ and $15 \mathrm{lbs}$ pressure for 15 minutes. To obtain a $\mathrm{pH}$ of 3.5, the sterilized cooled medium was acidified with $10 \mathrm{ml}$ of $10 \%$ sterile tartaric acid $(1 \mathrm{ml} / 100 \mathrm{~g}$ of media). Precaution was taken not to heat the medium after addition of the acid to preserve solidifying properties of agar. Duplicate sets of petri dishes were inoculated aseptically with $1 \mathrm{ml}$ of aliquots from appropriate dilutions. About 10-15 $\mathrm{ml}$ of melted agar, maintained at $44-46^{\circ} \mathrm{C}$ was poured gently in to each dish. The plates were incubated at $25^{\circ} \mathrm{C}$ for 5 days. Black, white, red and greenish coloured colonies appearing on the plates were counted and expressed as $\log _{10} \mathrm{cfu} / \mathrm{g}$.

\section{Sensory evaluation}

Sensory evaluation of dehydrated meat rings was conducted using an eight point descriptive scale (Keeton, 1983) with slight modifications, where $8=$ excellent and $1=$ extremely poor. The experienced panel consisting of scientists and post graduate students of the Division of Livestock Products 
Technology, IVRI, Izatnagar, evaluated the samples, and all the analyses were conducted in triplicate. Sensory evaluation was done at $25{ }^{\circ} \mathrm{C}$ and $60 \%$ relative humidity. The panelists were briefed with the nature of the experiments without disclosing the identity of the samples and were requested to rate them on an eight point descriptive scale on the sensory evaluation pro-forma for different attributes. Water was provided to rinse the mouth between tasting of each sample. The panelists evaluated the samples for attributes such as appearance/ colour, flavour, texture, crispness, milk flavor intensity, after taste and overall acceptability.

\section{Statistical analysis}

All the data were expressed as mean \pm standard error of mean calculated from three independent experiments. The data were analyzed by SPSS statistical software package using standard procedures (Snedecor and Cochran, 1995). Duncan's multiple range tests was used to determine significant difference among means for different treatments.

\section{Results and Discussion}

The products were aerobically packaged in low density polythene (LDPE) bags and analysed at regular intervals on $0,15^{\text {th }}, 30^{\text {th }}$, $45^{\text {th }}$ and $60^{\text {th }}$ day during storage at ambient temperature $\left(30 \pm 2^{\circ} \mathrm{C}\right) /$ conditions.

\section{Evaluation of changes in physico-chemical properties of control and selected treatment, during storage at ambient temperature}

Changes in the physico-chemical properties of the control and selected treatment were evaluated on days $0,15^{\text {th }}, 30^{\text {th }}, 45^{\text {th }}$ and $60^{\text {th }}$ days of storage. Dried products were evaluated before and after frying for suitable parameters. Mean \pm SE values of physico- chemical properties during storage are presented in Table 1.

\section{pH}

There was a significant $(\mathrm{p}<0.05)$ gradual increase in $\mathrm{pH}$ for control and treatment up to 45 days of storage and then significant $(\mathrm{p}<0.05)$ decrease on $60^{\text {th }}$ day. This might be due to the formation of free radicals, and then their subsequent conversion to non-radical products as Stapelfeldt et al., (1997) had observed the average content of free radicals in milk powders increased during storage, to a maximum at 47 days of storage, after which it declined toward the end of the storage period. Further, there was a significantly lower ( $>>0.05) \mathrm{pH}$ value for control than treatment during the entire storage period, might be due to higher amount of SMC.

\section{TBARS (mg malonaldehyde/kg)}

When milk and milk products are stored under aerobic condition, fat deterioration occurs and the milk constituents may be oxidized. During storage period, TBARS increased significantly $(\mathrm{p}<0.05)$ gradually in control as well as treatment product.

A general trend of increase in TBARS in milk powders during storage was reported by Stapelfeldt et al., (1997) who also reported that storage temperature has effects on formation of free radical precursors and TBARS increased steadily during storage of milk powders at $45^{\circ} \mathrm{C}$ while TBARS only increased slightly at $25^{\circ} \mathrm{C}$. The treatment product showed significantly lower $(\mathrm{p}<0.05)$ TBARS value than control on $0,15^{\text {th }}$ and $60^{\text {th }}$ day of storage but on $30^{\text {th }}$ and $45^{\text {th }}$ day the difference was non significant ( $p>0.05)$.

\section{Expansion percentage}

Expansion percentage of control decreased from initial value of $100.37 \pm 3.78 \%$ on 0 day 
to $54.30 \pm 3.79 \%$ on day 60 . For treatment, the expansion percentage decreased from initial value of $168.70 \pm 11.62 \%$ to $99.89 \pm$ $1.18 \%$ on day 60 of storage. The change in expansion percentage of both the products was non significant $(\mathrm{p}>0.05)$ up to $15^{\text {th }}$ day and there after it decreased significantly $(p<0.05)$ on $30^{\text {th }}$ and $45^{\text {th }}$ day and further remained non significant $(p>0.05)$ up to $60^{\text {th }}$ day of storage.

The decline in expansion percentage of control and treatment on storage might be attributed to its increased moisture value during storage. Conway (1971) and Park et al., (1993b) observed that the amount of moisture present in the products directly affects the composition of product as well as expansion ratio. Further, there was a significantly higher $(p>0.05)$ expansion percentage for treatment then control during the entire storage period, might be due to higher moisture and protein content in control. Martinez- Serna et al., (1990) and Onwulata et al., $(1998,2001)$ investigated the effects of whey protein concentrate and isolate on the extrusion of corn and rice starch and reported a reduction in expansion at higher concentrations of protein. Protein reduced expansion of amylopectin, which resulted in decreased number of pores in the fried rice crackers during frying (Yohii and Arisaka, 1994).

\section{Percentage oil uptake}

Percentage oil uptake of 'Milk Crisp' decreased gradually with storage for both control (from $21.82 \pm 2.96 \%$ to $18.63 \pm$ $2.31 \%)$ as well as treatment $(24.48 \pm 0.65 \%$ to $18.71 \pm 1.62 \%$ ) however the reduction was non significant $(p>0.05)$ in control up to 60 days and significant $(\mathrm{p}<0.05)$ in treatment only after $45^{\text {th }}$ day. It might be due to reduced degree of expansion. The decrease of oil content in the fried crackers could be explained by the reduced degree of expansion and film formation (Yohii and Arisaka, 1994). Lowering expansion was followed by decrease in specific surface area and number of pores in the fried crackers, which does not allow enough room for oil uptake; this is supported by the results of the texture analysis (Maneerote et al., 2009; Nurul et al., 2009).

Further, percentage oil uptake was significantly higher $(\mathrm{p}<0.05)$ for treatment up to 15 days, there after it remained non significantly $(p>0.05)$ higher than control. This could be attributed to lower SMC present in the treatment that makes more compact product on drying with lower in moisture percentage which leads to crust formation and offers fewer spaces/ acts as a barrier for absorption of oil during frying and also reduced degree of expansion and film formation.

\section{Colour value (Yellowness)}

There was no significant $(p>0.05)$ change in the yellowness value of the control up to $30^{\text {th }}$ day of storage which then increased significantly $(\mathrm{p}<0.05)$ on $45^{\text {th }}$ day and then increased. However, for treatment, there was no significant $(\mathrm{p}>0.05)$ change in yellowness value up to $30^{\text {th }}$ day of storage but there was significant $(\mathrm{p}<0.05)$ increase on $45^{\text {th }}$ and $60^{\text {th }}$ day. Not surprisingly, the non-enzymic browning, as measured directly from product colour, was favoured by the high storage temperature, in accordance with the results of Ipsen and Hansen (1988). Maillard reaction, a non-enzymatic browning reaction between amino acids and reducing sugars, is the primary color formation reaction (Baikand Mittal, 2003; Moyano et al., 2002). 
Table.1 Changes in physico-chemical properties of aerobically packaged control and selected treatment, during storage at ambient temperature (Mean \pm S.E) *

\begin{tabular}{|c|c|c|c|c|c|}
\hline \multirow[t]{2}{*}{ Particulars } & \multicolumn{5}{|c|}{ Days of storage } \\
\hline & $\mathbf{0}$ & 15 & 30 & 45 & 60 \\
\hline \multicolumn{6}{|c|}{$\mathrm{pH}$} \\
\hline Control & $5.21 \pm 0.02^{\mathrm{dB}}$ & $5.48 \pm 0.08^{\mathrm{cB}}$ & $5.78 \pm 0.04^{\mathrm{bB}}$ & $6.13 \pm 0.23^{\mathrm{aB}}$ & $5.46 \pm 0.05^{\mathrm{cB}}$ \\
\hline Treatment & $5.28 \pm 0.07^{\mathrm{dA}}$ & $5.51 \pm 0.01^{\mathrm{cA}}$ & $5.93 \pm 0.03^{\mathrm{bA}}$ & $6.39 \pm 0.04^{\mathrm{aA}}$ & $5.55 \pm 0.01^{\mathrm{cA}}$ \\
\hline \multicolumn{6}{|c|}{ TBARS (mg malonaldehyde/kg) } \\
\hline Control & $0.08 \pm 0.02^{\mathrm{eA}}$ & $0.13 \pm 0.01^{\mathrm{dA}}$ & $0.17 \pm 0.01^{\mathrm{c}}$ & $0.21 \pm 0.01^{\mathrm{b}}$ & $0.25 \pm 0.03^{\mathrm{aA}}$ \\
\hline Treatment & $0.05 \pm 0.01^{\mathrm{eB}}$ & $0.11 \pm 0.01^{\mathrm{dB}}$ & $0.16 \pm 0.01^{\mathrm{c}}$ & $0.19 \pm 0.01^{b}$ & $0.21 \pm 0.01^{\mathrm{aB}}$ \\
\hline \multicolumn{6}{|c|}{ Expansion percentage } \\
\hline Control & $100.37 \pm 3.78^{\mathrm{aB}}$ & $104.18 \pm 1.58^{\mathrm{aB}}$ & $83.84 \pm 2.71^{\mathrm{bB}}$ & $64.70 \pm 4.00^{\mathrm{cB}}$ & $54.3 \pm 3.79^{\mathrm{cB}}$ \\
\hline Treatment & $168.70 \pm 11.62^{\mathrm{aA}}$ & $161.08 \pm 2.23^{\mathrm{aA}}$ & $131.35 \pm 0.91^{\mathrm{bA}}$ & $110.02 \pm 2.36^{\mathrm{cA}}$ & $99.89 \pm 1.18^{\mathrm{cA}}$ \\
\hline \multicolumn{6}{|c|}{ Percentage oil uptake } \\
\hline Control & $21.82 \pm 2.96^{\mathrm{B}}$ & $20.24 \pm 1.45^{\mathrm{B}}$ & $19.51 \pm 1.26$ & $19.03 \pm 1.21$ & $18.63 \pm 2.31$ \\
\hline Treatment & $24.48 \pm 0.65^{\mathrm{aA}}$ & $22.32 \pm 0.98^{\mathrm{aA}}$ & $20.44 \pm 0.70^{\mathrm{a}}$ & $19.09 \pm 0.63^{b}$ & $18.71 \pm 1.62^{b}$ \\
\hline \multicolumn{6}{|c|}{ Colour value } \\
\hline Control & $0.037 \pm 0.012^{\mathrm{bB}}$ & $0.046 \pm 0.012^{\mathrm{bB}}$ & $0.056 \pm 0.008^{\mathrm{abB}}$ & $0.086 \pm 0.008^{\mathrm{aB}}$ & $0.097 \pm 0.035^{\mathrm{aB}}$ \\
\hline Treatment & $0.116 \pm 0.003^{\mathrm{cA}}$ & $0.120 \pm 0.005^{\mathrm{cA}}$ & $0.136 \pm 0.009^{\mathrm{cA}}$ & $0.176 \pm 0.008^{\mathrm{bA}}$ & $0.243 \pm 0.024^{\mathrm{aA}}$ \\
\hline \multicolumn{6}{|c|}{ Moisture (\%) } \\
\hline Control & $10.26 \pm 0.28^{\mathrm{aA}}$ & $10.75 \pm 0.05^{\mathrm{aA}}$ & $12.43 \pm 0.05^{\mathrm{bA}}$ & $12.95 \pm 0.05^{\mathrm{cA}}$ & $13.13 \pm 0.03^{\mathrm{cA}}$ \\
\hline Treatment & $7.50 \pm 0.07^{\mathrm{aB}}$ & $7.64 \pm 0.16^{\mathrm{aB}}$ & $8.29 \pm 0.07^{\mathrm{bB}}$ & $8.88 \pm 0.04^{\mathrm{cB}}$ & $9.07 \pm 0.05^{\mathrm{cB}}$ \\
\hline
\end{tabular}

$\mathrm{n}=6$ for each treatment.

*Mean \pm S.E. with different superscripts row wise (small letter) and column wise (capital letter)

differ significantly $(\mathrm{p}<0.05)$.

Table.2 Changes in microbiological qualities of aerobically packaged control and selected treatment, during storage at ambient temperature (Mean \pm S.E)*

\begin{tabular}{|c|c|c|c|c|c|}
\hline \multirow[t]{2}{*}{ Particulars } & \multicolumn{5}{|c|}{ Days of storage } \\
\hline & $\mathbf{0}$ & 15 & 30 & 45 & 60 \\
\hline \multicolumn{6}{|c|}{ Total plate count (log cfu/g) } \\
\hline Control & $2.49 \pm 0.01^{\mathrm{aB}}$ & $3.06 \pm 0.03^{b}$ & $4.16 \pm 0.12^{\mathrm{dB}}$ & $4.29 \pm 0.29^{\mathrm{dB}}$ & $3.88 \pm 0.19^{c}$ \\
\hline Treatment & $2.76 \pm 0.04^{\mathrm{aA}}$ & $3.14 \pm 0.08^{b}$ & $4.36 \pm 0.32^{\mathrm{dA}}$ & $4.46 \pm 0.38^{\mathrm{dA}}$ & $3.94 \pm 0.11^{\mathrm{c}}$ \\
\hline \multicolumn{6}{|c|}{ Yeast and mould count $(\log \mathrm{cfu} / \mathrm{g})$} \\
\hline Control & ND & $1.48 \pm 0.07^{\mathrm{aB}}$ & $1.91 \pm 0.06^{\mathrm{bB}}$ & $2.56 \pm 0.09^{\mathrm{cB}}$ & $3.16 \pm 0.18^{\mathrm{dB}}$ \\
\hline Treatment & ND & $1.86 \pm 0.02^{\mathrm{aA}}$ & $2.11 \pm 0.03^{\mathrm{aA}}$ & $2.73 \pm 0.12^{\mathrm{bA}}$ & $3.31 \pm 0.12^{\mathrm{cA}}$ \\
\hline
\end{tabular}


Table.3 Changes in the sensory properties of control and selected treatment, during storage at ambient temperature (Mean \pm S.E)

\begin{tabular}{|c|c|c|c|c|c|}
\hline \multirow[t]{2}{*}{ Particulars } & \multicolumn{5}{|c|}{ Days of storage } \\
\hline & $\mathbf{0}$ & 15 & 30 & 45 & 60 \\
\hline \multicolumn{6}{|c|}{ Appearance and Colour } \\
\hline Control & $6.70 \pm 0.13^{\mathrm{B}}$ & $6.63 \pm 0.19^{B}$ & $6.57 \pm 0.12^{\mathrm{B}}$ & $6.53 \pm 0.18^{B}$ & $6.44 \pm 0.11^{\mathrm{B}}$ \\
\hline Treatment & $7.27 \pm 0.13^{\mathrm{A}}$ & $7.18 \pm 0.12^{\mathrm{A}}$ & $7.11 \pm 0.18^{\mathrm{A}}$ & $7.05 \pm 0.08^{\mathrm{A}}$ & $6.84 \pm 0.12^{\mathrm{A}}$ \\
\hline \multicolumn{6}{|c|}{ Flavour } \\
\hline Control & $6.35 \pm 0.11^{\mathrm{B}}$ & $6.27 \pm 0.11^{\mathrm{B}}$ & $6.24 \pm 0.14^{\mathrm{B}}$ & $6.23 \pm 0.5^{\mathrm{B}}$ & $6.14 \pm 0.14^{\mathrm{B}}$ \\
\hline Treatment & $6.98 \pm 0.15^{\mathrm{A}}$ & $6.63 \pm 0.10^{\mathrm{A}}$ & $6.57 \pm 0.09^{\mathrm{A}}$ & $6.43 \pm 0.13^{\mathrm{A}}$ & $6.27 \pm 0.15^{\mathrm{A}}$ \\
\hline \multicolumn{6}{|c|}{ Texture } \\
\hline Control & $6.45 \pm 0.19$ & $6.77 \pm 0.14$ & $6.78 \pm 0.15$ & $6.52 \pm 0.19$ & $6.42 \pm 0.13$ \\
\hline Treatment & $6.95 \pm 0.20$ & $6.97 \pm 0.11$ & $6.96 \pm 0.09$ & $6.69 \pm 0.14$ & $6.63 \pm 0.44$ \\
\hline \multicolumn{6}{|c|}{ Crispness } \\
\hline Control & $6.63 \pm 0.11^{\mathrm{aB}}$ & $6.53 \pm 0.12^{\mathrm{bB}}$ & $6.37 \pm 0.16^{\mathrm{cB}}$ & $6.23 \pm 0.16^{\mathrm{cB}}$ & $6.11 \pm 0.15^{\mathrm{dB}}$ \\
\hline Treatment & $7.00 \pm 0.10^{\mathrm{aA}}$ & $6.87 \pm 0.16^{\mathrm{bA}}$ & $6.51 \pm 0.11^{\mathrm{cA}}$ & $6.39 \pm 0.26^{\mathrm{cA}}$ & $6.21 \pm 0.14^{\mathrm{dA}}$ \\
\hline \multicolumn{6}{|c|}{ After-taste } \\
\hline Control & $6.18 \pm 0.25^{\mathrm{B}}$ & $6.46 \pm 0.15^{\mathrm{B}}$ & $6.54 \pm 0.16^{\mathrm{B}}$ & $6.41 \pm 0.22^{\mathrm{B}}$ & $6.29 \pm 0.22^{\mathrm{B}}$ \\
\hline Treatment & $7.03 \pm 0.14^{\mathrm{A}}$ & $7.17 \pm 0.11^{\mathrm{A}}$ & $7.00 \pm 0.16^{\mathrm{A}}$ & $6.76 \pm 0.13^{\mathrm{A}}$ & $6.66 \pm 0.18^{A}$ \\
\hline \multicolumn{6}{|c|}{ Milk flavour intensity } \\
\hline Control & $6.18 \pm 0.25$ & $6.46 \pm 0.15$ & $6.54 \pm 0.16$ & $6.29 \pm 0.26$ & $6.22 \pm 0.19$ \\
\hline Treatment & $6.08 \pm 0.27$ & $6.23 \pm 0.13$ & $6.07 \pm 0.19$ & $6.03 \pm 0.39$ & $6.01 \pm 0.23$ \\
\hline \multicolumn{6}{|c|}{ Overall Acceptability } \\
\hline Control & $6.80 \pm 0.27^{\mathrm{aB}}$ & $6.78 \pm 0.1^{\mathrm{aB}}$ & $6.77 \pm 0.21^{\mathrm{aB}}$ & $6.73 \pm 0.20^{\mathrm{abB}}$ & $6.69 \pm 0.19^{\mathrm{bB}}$ \\
\hline Treatment & $7.30 \pm 0.16^{\mathrm{aA}}$ & $7.24 \pm 0.16^{\mathrm{aA}}$ & $7.11 \pm 0.19^{\mathrm{bA}}$ & $7.03 \pm 0.52^{\mathrm{cA}}$ & $6.93 \pm 0.45^{\mathrm{dA}}$ \\
\hline
\end{tabular}

\section{Moisture content}

Moisture percentage of the treatment was 7.50 $\pm 0.07 \%$ on 0 day and it increased to $9.07 \pm$ $0.05 \%$ on day 60 of storage. For the control moisture percentage increased from $10.26 \pm$ $0.28 \%$ on day 0 to $13.13 \pm 0.03 \%$ on day 60 . However, the increase was non significant ( $>>0.05$ ) up to $15^{\text {th }}$ day then after it was significant $(\mathrm{p}<0.05)$ on $30^{\text {th }}$ and $45^{\text {th }}$ day and further remained non significant $(p>0.05)$. De-Freits and Molins (1988) found increases in moisture contents from 0.9 to $2.8 \%$ in meat snack dips during 40 days of storage in LDPE
(150 gauge) + polypropylene pouches (120 gauge) at $30-35^{\circ} \mathrm{C}$ under same packaging and storage conditions. Further, the moisture percentage of control remained significantly higher $(\mathrm{p}<0.01)$ than the treatment during the entire period of storage.

Evaluation of changes in the microbiological quality of control and selected treatment, during storage at ambient temperature

Cereal based snacks are indefinitely shelf stable (De-Freites and Molins, 1988). 
However, incorporation of dairy ingredients alters its microbiological and stability characteristics (Draughon, 1980; Harrison et al., 1983). Park et al., (1993b) reported very low count of aerobic bacteria, yeast and moulds, coli forms and E. coli in the extruded breakfast cereals and cereal based snack products stored up to 150 days at $37^{\circ} \mathrm{C}$.

Microbiological quality of the control and treatment was assessed on $0,15^{\text {th }}, 30^{\text {th }}, 45^{\text {th }}$ and $60^{\text {th }}$ day of storage. Mean \pm SE values of total plate count and yeast and mould count are presented in Table 2.

\section{Yeast and mould count}

The yeast and mould was not detected on the day product were prepared. Then after a significant $(p<0.05)$ gradual increase was observed in control during the entire storage period. In treatment, the significant increase was observed on $45^{\text {th }}$ day onwards. During the entire storage period, yeast and mould count for treatment was higher than control.

\section{Evaluation of changes in sensory characteristics of control and selected treatment, during storage at ambient temperature}

Mean \pm SE values of sensory characteristics of 'Milk Crisp' during storage are presented in Table 3. The scores for appearance and colour of treatment decreased from $7.27 \pm$ 0.13 (day 0) to $6.84 \pm 0.12$ (day 60) and for control decreased from $6.70 \pm 0.13$ (day 0) and $6.44 \pm 0.11$ (day 60). However, these scores did not differ significantly $(\mathrm{p}>0.05)$ for both control and treatment during storage period. Further, treatment had significantly higher $(p<0.05)$ value than control during entire storage period.

The scores for flavour of treatment decreased from $6.98 \pm 0.15$ (day 0) to $6.27 \pm 0.15$ (day
60) and for control decreased from $6.35 \pm$ 0.11 (day 0) and 6.14 \pm 0.14 (day 60). However, these scores did not differ significantly $(p>0.05)$ for both control and treatment during storage period. Further, treatment had significantly higher $(\mathrm{p}<0.05)$ value than control during entire storage period.

The texture scores decreased from $6.95 \pm 0.20$ (day 0) to $6.63 \pm 0.44$ (day 60) for treatment, whereas for control the scores decreased from $6.45 \pm 0.19$ on day 0 to $6.42 \pm 0.13$ on $60^{\text {th }}$ day. Texture of fried snacks did not change significantly $(p>0.05)$ for control as well as treatment during the entire storage period. In addition, there was no significant difference $(p>0.05)$ in the texture scores between control and treatment on any particular day of storage.

The crispness scores decreased from $6.63 \pm 0.11$ (day 0) to $6.11 \pm 0.15$ (day 60) for control, whereas for treatment, the scores decreased from $7.00 \pm 0.10$ on day 0 to $6.21 \pm 0.14$ on day 60 . However, the decline was significant $(\mathrm{p}<0.05)$ up to $30^{\text {th }}$ day and non significant $(\mathrm{p}>0.05)$ on $45^{\text {th }}$ day and further significant on $60^{\text {th }}$ day of storage in both the samples studied. Further, score for treatment was significantly higher in treatment than control during the entire storage period. The scores for after taste of control decreased from $6.18 \pm 0.25$ (day 0 ) to $6.29 \pm 0.22$ (day 60) and for treatment decreased from $7.03 \pm 0.14$ (day 0) and $6.66 \pm$ 0.18 (day 60). However, these scores did not differ significantly $(p>0.05)$ for both control and treatment during storage period. Further, treatment had significantly higher $(\mathrm{p}<0.05)$ value than control during entire storage period.

There was no significant difference observed in milk flavour intensity scores of control and treatment product throughout entire period of 
storage study. Further, no significant difference was observed between control and treatment during the storage days.

The scores for overall acceptability were 6.80 \pm 0.27 on day 0 and $6.69 \pm 0.19$ on $60^{\text {th }}$ day for treatment and for control, the values were $7.30 \pm 0.16$ (day 0) and $6.93 \pm 0.45$ (day 60). The control product showed a significant decline in score on $60^{\text {th }}$ day of storage and the treatment showed on $30^{\text {th }}$ day onwards. Further, score for treatment was significantly higher in treatment than control during the entire storage period.

In conclusion the selected treatment and control were packaged in LDPE bags and changes in their quality were studied for 60 days at the regular interval of 15 days. There was an increasing trend in $\mathrm{pH}$ for control as well as for treatment up to 45 days of storage, after which it declined towards the end of the storage period studied. Oil uptake percentage and expansion percentage showed decreasing trends for both control and treatment. During storage, there was a significant increase in the TBARS value for control as well as treatment. Microbial profile showed that there was a significant $(\mathrm{p}<0.05)$ gradual increase in TPC for control and treatment up to 30 days and then non-significant increase on 45th day of storage followed by a significant $(p<0.05)$ decrease was observe on 60th day. The yeast and mould was not detected on the day products were prepared. There after a significant $(p<0.05)$ gradual increase was observed in control during the entire storage period. In treatment, the significant increase was observed on 45th day onwards. During storage period, there was no significant reduction in sensory attribute scores. The products were observed to have overall acceptability varying between good to very good range. Drying at $45^{\circ} \mathrm{C}$ for 24 hours was found out to be the suitable time temperature combination without inducing case hardening.
Dried milk-based snacks can be fried at $190^{\circ} \mathrm{C}$ for $10-15$ seconds without producing burnt flavour.

The developed 'Milk Crisp' could be kept well without marked changes in quality for 60 days at ambient temperature when packaged aerobically in LDPE pouches.

\section{Declaration of interest}

The authors report no conflicts of interest. The authors alone are responsible for the content and writing of the paper.

\section{References}

AOAC. (1995). Official Method of Analysis. 16th edn. Association of Official Analytical Chemists. Washington D.C.

APHA, 1984. Compendium of methods for the microbiological examination of foods. $2^{\text {nd }}$ Ed. (Ed: M.L Speck). American Public Health Association., Washington, DC.

Baik, D. O. and Mittal, S. G. 2003. Kinetics of tofu color changes during deep-fat frying. Lebensmittel-Wissenschaft-undTechnologie, 36:43-48.

Bhattacharya, D. C., Mathur, O. N., Srinivashan, M. P and Samlik, O. (1971). Studies on the methods of production and shelf life of paneer. Journal of food science and technology 8:117-120.

Bhattacharya, M., Hanna, M. A. and Kaufman, R. E. (1999). Textural properties of extruded plant protein blends. J. Food Sci., 51: 988993.

Conway, H.F 1971. Extrusion cooking of cereals and soybean. Part 1. Food Prod. Dev., 5:14

De-Freitas, Z. and Molins, R.A. 1988. Development of meat snack dips: chemical, physical, microbiological and sensory characteristics, journal of food science, 53(6): 1645-1649.

Draughon, F.A. 1980. Effect of plant derived extenders on microbial stability of foods. Food Technol., 34: 69-74.

Froehlich, D. A., Gullet, E. A. and Usborne, W. R. (1983). Effect of nitrite and salt on the 
colour, flavour and overall acceptability of ham. Journal of Food Science 48:152-154.

Harrison, M.A., Draughon, F.A. and Melton, C.C. 1983. Inhibition of spoilage bacteria by acidification of soy extended ground beef. Journal of food science, 48: 825-828.

Ipsen, R. and Hansen, P. S. 1988. Factors affecting the storage stability of whole milk powder. (Report No. 274). Statens Mejeriforsng, Hillererd, Denmark.

Keeton, J. T. (1983). Effect of fat and sodium chloride/phosphate levels on the chemical and sensory properties of pork patties.Journal of Food Science48: 878-85.

Maneerote, J., Noomhorm, A. and Takhar, P. S. 2009. Optimization of processing conditions to reduce oil uptake and enhance physico-chemical properties of deep-fried rice crackers. LWT - Food Science and Technology, 42: 805-812.

Martinez-Serna, M., Hawkes, J. and Villota, R., 1990. Extrusion of natural and modified whey proteins in starch-based systems. In: Press, W.E.L.

Moyano, C. P. and Predreschi, F. 2006. Kinetic of oil uptake during frying of $\backslash$ potato slices: effect of pre-treatment. LWT-Food Science and Technology, 39:285-291.

Nurul, H., Boni, I. and Noryati, I. 2009. The effect of different ratios of dory fish to tapioca flour on the linear expansion, oil absorption, colour and hardness of fish crackers. International Food Research Journal, 16:159-165.

Onwulata, C.I., Konstance, R.P., Smith, P.W. and Holsinger, V.H. 1998. Physical properties of extruded products as affected by cheese whey. J. FoodSci., 63:814-818.

Park, J., Rhee, K.S., Kim, B.K. and Rhee, K.C. 1993b, High Protein texturized Product of Defatted Soy Flour, Corn Starch and Beef: Shelf-Life, Physical and Sensory
Properties. J. Food Sci, 58: 21-27.

Pearson, D. (1976). The Dictionary of Nutrition and Food Technology. Fifth edition. Butter Worth Publisher London.

Pinthus, E. J., Fan, J. and Singh, R. P. (1993). Physicochemical changes in starch during deep fat frying of a molded corn starch patty. Journal of Food Processing and Preservation 21: 443-460.

Smith, G. L., Stadler, J. W., Keeton, J. T. and Papadopoulos, L. S. (1991). Evaluation of partially defatted chopped beef in fermented beef snack sausage. Journal of Food Science 56: 348-351.

Snedecor, G. W. and Cochran, W. G. (1995). Statistical methods, $8^{\text {th }}$ Ed. IOWA State University Press Ames IOWA.

Stapelfeldt. H., ijorn, H., Skovgaard. I. M., Skibsted, L. H. and Bertelsen, G. 1992. Warmed-over flavour in cooked sliced beef. Chemical analysis in relation to sensory evaluation. Zeitschrifi flier Lehen.smittel-UntersuchungundForschung, 195:203-208.

Tarladgis, B. G., Watts, B. M., Younathan, M. T. and Dugan, L. R. (1960). A distillation method for the quantitative determination of malonaldehyde in rancid foods. Journal of American Oil Chemist Society37:403-06.

Trout, E. S., Hunt, M. C., Johnson, D. E., Claus, J. R., Kastner, C. L. and Kropt, D. H. (1992). Characterstics of low-fat ground beef containing texture modifying ingredients. Journal of Food Science, 57(1):19-24.

Yohii, Y. and Arisaka, M. 1994. Relationships between physicochemical properties of nonglutinous rice and degree of expansion of rice cracker. Journal of The Japanese Society for Food Science and Technology Nippon Shokuhin Kagaku KogakuKaishi, 41(11):747-754.

\section{How to cite this article:}

Bhujendra Soni, Geeta Chauhan, S. K. Mendiratta, Subhashis Mohapatra and Anuradha Yadav. 2020. Evaluation of Changes in the Microbiological Quality, Physic-chemical Properties and Sensory Properties of Milk-based Snack "Milk Crisp" during Storage at Ambient Temperature. Int.J.Curr.Microbiol.App.Sci. 9(09): 22-33. doi: https://doi.org/10.20546/ijcmas.2020.909.003 